\title{
PATAl, Daphne. História Oral, Feminismo e Política. São Paulo: Letra e Voz, 2010, 163 p.
}

\section{Marta Gouveia de Oliveira Rovai*}

“Com os anos, percebi claramente que não há nenhuma filiação política, filosófica, religiosa, doutrinária, etc. que garanta comportamento íntegro e honesto no mundo, nem que impeça a corrupção, o egocentrismo, a crueldade, a injustiça.” Assim a estudiosa norteamericana Daphne Patai inicia o livro História Oral, Feminismo e Política (São Paulo: Letra e Voz, 2010), um conjunto de oito ensaios selecionados por ela, representativos de sua competente e ousada trajetória como intelectual.

Grande estudiosa das relações de gênero e da história oral, sem filiação a nenhuma linha teórica ou política, e sempre inspirando reflexões com seus questionamentos provocativos, a professora de Literatura Brasileira na Universidade de Massachusetts tem, pela primeira vez, alguns de seus textos traduzidos para o português. Mesmo assim, desde seu primeiro trabalho com história de vida de mulheres brasileiras, nos anos 80, sua postura sensível e atenta às expressões verbais e à textualização das narrativas já chamava a atenção de diversos intelectuais, como Ecleá Bosi e José Carlos Sebe Bom Meihy ${ }^{1}$.

As colocações iniciais do livro são também o ponto de chegada: uma constante, sofisticada e inacabada autocrítica acerca de crenças utópicas e ingênuas, repensadas ao longo

\footnotetext{
* Doutoranda em História Social e Pesquisadora do Núcleo de Estudos em História Oral (NEHO) da Universidade de São Paulo. E-mail: martarovai@usp.br

${ }^{1}$ BOSI, E. Memória e sociedade: lembrança de velhos. São Paulo: Cia. Das Letras, 1979; MEIHY, José C.S.B. A colônia brasilianista: história oral de vida acadêmica. São Paulo: Nova Stella, 1990.
} 
de sua vida intelectual e a preocupação ética com o uso político/acadêmico da história oral por pesquisadores, em especial nos estudos feministas.

O primeiro texto apresentado, Construindo um eu: uma história ora de mulheres brasileiras, parte do livro Brazilian Women Speak (New Brunswick: Rugers University Press, 1988), consiste no esforço de Patai em ouvir e compreender histórias de vida de mulheres nas cidades de Recife e do Rio de Janeiro, durante os anos 80, ainda no contexto da Ditadura Militar. Mulheres comuns, mas não insignificantes, pois não há, segundo ela, vidas sem sentido e sim revelações que desconhecemos. Com esse trabalho, a pesquisadora inaugura a discussão ética presente nos demais ensaios.

A entrevista é pensada por ela não apenas como um projeto acadêmico; é relação dialógica, resultado da intersecção entre duas subjetividades, duas visões culturais, duas percepções e condições socais distintas, o que requer um cuidado ético quanto à interferência, à coleta, à exposição e ao uso das narrativas de vida pelo pesquisador, eivtando incorrer no perigo de "recriarmos o mundo que estamos tentando desfazer". Ao entrevistar mulheres, Patai aponta a importância da escuta atenta, intensa e da garantia à autonomia do narrador que, apesar de sujeito aos interesses do entrevistador, tem suas próprias intenções, objetivos e escolhe o que quer dizer, procurando dar sentido às ações que narra por meio da linguagem. Por isso, a textualização dos relatos deve prestar atenção à evocação verbal, ao ritmo e à entonação nas performances.

Essa reflexão ética permanece na peça Problemas éticos de narativas pessoais ou, quem vai ficar com o último pedaço do bolo? publicada em 1987, quando aprofunda os questionamentos em torno do uso que fez das entrevistas com as mulheres brasileiras, preocupada com seus propósitos acadêmicos e com a exposição das histórias de vida. A autora relata como escreveu para dezenas de pessoas para compartilhar suas angústias sobre as implicações éticas do uso de narrativas. Dentre as várias respostas que recebeu, destaca a que sugere a devolução das entrevistas aos “colaboradores” para serem revistas e autorizadas, um problema que ultrapassa a pesquisa acadêmica e que permanece aberto à discussão. Sua preocupação é mostrar que a questão ética no tratamento das entrevistas deve ir além das carreiras e da produção de conhecimento, envolvendo também compromissos com "objetos de pesquisa humanos”, a apropriação da vida do narrador, sem desrespeitar sua autonomia e interesses.

O desrespeito pelo narrador é o tema de Quem chama quem de “subalterno"?, texto de 1988, em que Daphne Patai questiona a competência dos intelectuais que trabalham com história oral para estabelecer critérios de hierarquia, o conceito de "subalterno" para tratar 
certos grupos sociais, e o direito de indicar a importância de uma narrativa ou a relevância de sua fala. As mulheres que entrevistou, duplamente nas sombras, por sua condição social e de gênero, poderiam ser consideradas subalternas, e suas narrativas, irrelevantes? Em nome de que conhecimento isso poderia ser feito? As mulheres entrevistadas não são uma categoria pré-estabelecida e generalizante, mas pessoas a serem ouvidas e consideradas em seus direitos. O respeito às suas vidas, às suas crenças, a seus “eus”, e o reconhecimento de que o trabalho de pesquisador é imperfeito, repleto de limitações, são os aspectos que a intelectual reivindica nos trabalhos com história oral e feminismo.

Nos textos seguintes, O que há de errado com os estudos da Mulher? (1995) e Chega de solipsismo nouveau dos acadêmicos (1994), Patai radicaliza sua postura em relação a algumas intelectuais e à sua própria crença até então, de que os estudos feministas seriam sinônimos de uma postura diferencial e mais ética do que a masculina. Após anos envolvida com os Estudos da Mulher, a estudiosa afirma que essa experiência provocou o desejo de rompimento com um certo tipo de empoderamento de algumas mulheres nas academias. Percebendo a intolerância nos códigos de discurso e políticas de assédio sexual e as difamações em nome da igualdade, a autora aponta exageros nas práticas feministas estadunidenses, muitas vezes consideradas masculinas. Um novo vocabulário criado por estudiosas e militantes demonstra a rejeição a qualquer coisa “contaminada” pelos homens e interfere na dinâmica de salas de aulas, cursos e procedimentos acadêmicos, descambando para manifestos doutrinários que exaltam valores considerados verdades feministas, como honestidade e ética. Essa prática, segundo ela, permitiu julgamentos sem fundamento, transformando a academia em campo de luta política e o movimento feminista numa atitude beata, desdenhosa e solipsista.

Daphne Patai condena a convergência entre militância e academia, lembrando que o intelectual não é a vanguarda política, escolhendo quem pode ou não falar em nome de quem ou validando verdades a partir de interesses políticos, discussão que fica mais clara em $A$ verdade de quem? Iconicidade e exatidão no universo da literatura testemunhal, texto publicado em 2001, quando a pesquisadora apresenta o debate intelectual em torno da qualificação do testemunho, a partir do livro Me llamo Rigoberta Menchú.

A grande questão nesse momento é sobre a validade do testemunho de Rigoberta Menchú, guatemalteca que se apropriou de fatos políticos relativos à história de vida de outras pessoas, como a tortura, como partes de sua vida e representativos da memória de seu povo. Bandeiras como o feminismo ou a "justiça social” levam professores estadunidenses a validar sua narrativa como denúncia da realidade opressora da Guatemala, aceitando suas deturpações 
e omissões. Patai pergunta se os intelectuais devem tornar a verdade subserviente aos interesses políticos e quais as implicações disso para o conhecimento. A autora não nega que a memória seja inexata e tenha suas próprias construções, e que a experiência seja significada pelo narrador, porém considera que “as pequenas mentiras da memória” não devem ser confundidas com deturpações e mentiras que podem se propagar e trazer implicações perigosas politicamente. A militância não pode ser mais importante que o conhecimento em si, discussão que se aprofunda nos textos mais atuais da coletânea, História oral e feminismo: uma revisão crítica (2008) e A face evanescente do humanismo (2005), quando reconhece o empoderamento e ao mesmo tempo a fraqueza das práticas feministas quando os compromissos políticos são colocados acima das escolhas metodológicas.

A história oral feminista abriu um campo de reflexão e de ação em torno de políticas públicas, o que inspirou outros grupos identitários que também pretendem se fazer ouvir. No entanto, a política de identidade levada ao extremo fez desaparecer o humano, o "eu" compreendido em seus direitos e singularidades. A reivindicação de pertencimento a categorias e a "política da queixa”, segundo Patai, levou ao declínio da liberdade de expressão e a ações que privilegiam determinados grupos em detrimento de outros. O dogma do construcionismo social e a retórica do pós-modernismo são, para ela, os inimigos do humanismo, forçando os indivíduos a serem reconhecidos apenas enquanto em grupo, e assim também seus discursos. Esse teria sido o erro do feminismo solipsista, considerando-se capaz de qualificar conhecimentos produzidos nas universidades. A subjetividade e o humanismo ficam vulneráveis a abusos provenientes de reivindicações de grupos identitários, enquanto os argumentos racionais perdem espaço para a violência e os dogmas.

A leitura de cada texto nessa coletânea inquieta o leitor em torno de questões como a produção de conhecimento e os comprometimentos exagerados com políticas identitárias. Não que a luta por direitos coletivos seja desvalorizada pela autora, mas sua sensibilidade está sempre atenta às implicações decorrentes dos exageros políticos. Patai não revê suas posições para negá-las, mas para as reavaliar e complementar. É fundamental levar em conta criticamente a própria posição e as circunstâncias de produção do conhecimento. Aquilo que era vergonhoso na academia - o reconhecimento das próprias imperfeições e a postura autocrítica - deve ser impetuoso à história oral e ao feminismo?

Recebido em: Agosto/2010 Aprovado em: Novembro/2010 